\title{
PHYSICAL DEVELOPMENT AND BODY COMPOSITION PARAMETERS IN 4-11-YEAR-OLD CHILDREN
}

\section{ROZWÓJ FIZYCZNY I PARAMETRY SKŁADU CIAŁA DZIECI W WIEKU 4-11 LAT}

\author{
Ivan Čillík ${ }^{1(\mathrm{~A}, \mathrm{~B}, \mathrm{D}, \mathrm{E}, \mathrm{G})}$, Tomáš Willwéber ${ }^{1(\mathrm{~A}, \mathrm{C}, \mathrm{E}, \mathrm{F})}$
}

Authors' contribution Wkład autorów:

A. Study design/planning zaplanowanie badań B. Data collection/entry zebranie danych C. Data analysis/statistics dane - analiza i statystyki D. Data interpretation interpretacja danych E. Preparation of manuscript przygotowanie artykułu F. Literature analysis/search wyszukiwanie i analiza literatury G. Funds collection zebranie funduszy
Tables: 1

Figures: 9

References: 19

Submitted: 2017 Nov 20

Accepted: 2018 Feb 02
${ }^{1}$ Matej Bel University, Banská Bystrica, the Slovak Republic

\section{Summary}

Background. In this paper, we present the results of the study concerning body development and body composition parameters dependency.

Material and methods. The monitored sample consisted of 78 probands aged of $4-11$ years: group I, $4-5$ year-olds (13 probands) $5.17 \pm 0.52$ years; group II, $6-7$ year-olds ( 30 probands) $6.99 \pm 0.52$ years; group III, 8 - 9 year-olds ( 25 probands) $8.8 \pm 0.52$ years; group IV, $10-11$ year-olds (10 probands) $10.92 \pm 0.53$ years. To diagnose parameters of body composition the InBody 120 device was used.

Results. As for the parameters of body composition, a rising linear trend was recorded with increasing age. Statistically significant $(p<0.05)$ values were found between age groups in body height $(p=3.76 \mathrm{E}-24)$, body weight $(p=4.65 \mathrm{E}-16)$, quantity of fat mass $(p=0.0475)$, quantity of skeletal muscles ( $p=1.31 \mathrm{E}-20)$, total quantity of water in body $(p=2.23 \mathrm{E}-20)$, quantity of proteins $(p=1.83 \mathrm{E}-20)$, quantity of minerals $(\mathrm{p}=2.06 \mathrm{E}-19)$ and in the level of basal metabolism $(\mathrm{p}=1.77 \mathrm{E}-20)$.

Conclusions. Our results of body height and body weight correspond to those obtained in national anthropometric measurements. BMI values respond to the developmental trends, but they differ in the achieved values of comparable age groups as our probands have achieved lower values than the Slovak population.

Keywords: somatic parameters, bio-impedance, overweight, age differences

\section{Streszczenie}

Wprowadzenie. Artykuł przedstawia wyniki badań dotyczących rozwoju ciała i parametrów jego składu. W badaniach wzięły udział dzieci w wieku przedszkolnym i młodszym.

Materiał i metody. Monitorowana grupa składała się z 78 uczestników w wieku 4 - 11 lat, w tym 13 dzieci w wieku 4 - 5 lat, 5,17 $\pm 0,52$ lat; 30 - w wieku 6 - 7 lat, 6,99 $\pm 0,52$ lat; 25 w wieku 8 - 9 lat, $8,8 \pm 0,52$ lat oraz $10-$ w wieku 10 - 11 lat, $10,92 \pm 0,53$ lat. Do przeprowadzenia badań i zdiagnozowania parametrów składu ciała uży to urządzenia InBody 120.

Wyniki. Odnotowano liniowy trend wzrostowy w parametrach składu ciała związany $\mathrm{z}$ wiekiem badanych. Statystycznie istotne wartości $(\mathrm{p}<0,05)$ odnotowano między grupami wiekowymi a wysokością $(p=3,76 \mathrm{E}-24)$, masą ciała $(\mathrm{p}=4,65 \mathrm{E}-16)$, ilością masy tłuszczowej $(\mathrm{p}=0,0475)$, liczbą mięśni szkieletowych $(\mathrm{p}=1,31 \mathrm{E}-20)$, całkowitą ilością wody w ciele ( $\mathrm{p}$ $=2,23 \mathrm{E}-20)$, ilością białek $(\mathrm{p}=1,83 \mathrm{E}-20)$, ilością minerałów $(\mathrm{p}=2,06 \mathrm{E}-19)$ oraz poziomem podstawowego metabolizmu ( $\mathrm{p}=1,77 \mathrm{E}-20)$.

Wnioski.Uzyskane wyniki dotyczące wysokości i masy ciała odpowiadają trendom krajowych pomiarów antropometrycznych. Wartości BMI zgodne są z tendencjami rozwojowymi, ale różnią się osiągniętymi wartościami porównywalnych grup wiekowych, gdyż badana grupa badawcza osiągnęła niższe wartości niż populacja słowacka.

Słowa kluczowe: parametry somatyczne, bioimpedancja, nadwaga, różnice wieku

Čillík I, Willwéber T. Physical development and body composition parameters in 4-11-year-old children. Health Prob Civil. 2018; 12(1): 49-56. https://doi.org/10.5114/hpc.2018.74190

Address for correspondence / Adres korespondencyjny: Ivan Čillík, Department of Physical Education and Sports, Faculty of Arts, Matej Bel University, Banská Bystrica, Tajovského 40, 974 01, Banská Bystrica, the Slovak Republic, e-mail: ivan.cillik@umb.sk

Copyright: (C) Pope John Paul II State School of Higher Education in Biała Podlaska, Ivan Čillík, Tomáš Willwéber. This is an Open Access journal, all articles are distributed under the terms of the Creative Commons Attribution-NonCommercial-ShareAlike 4.0 International (CC BY-NC-SA 4.0) License (http://creativecommons. org/licenses/by-nc-sa/4.0/), allowing third parties to copy and redistribute the material in any medium or format and to remix, transform, and build upon the material, provided the original work is properly cited and states its license. 


\section{Introduction}

Childhood obesity is one of the most severe problems of public health in the $21^{\text {st }}$ century. The problem is global, and it constantly affects many countries with low and middle income, mainly in urban environments. Worldwide, the number of overweight children at the age of five was estimated to be over 42 million in 2015 [1].

It is assumed that overweight children and those with obesity will remain obese up to the adulthood, and cardiovascular and locomotor diseases are likely to occur in many of them. Therefore, monitoring the indicators and prevention of childhood obesity require particular attention [1].

The authors note that in overweight children, the risk of becoming overweight in adulthood is minimally twice as high as in children with healthy weight when transferring obesity to adulthood [2]. Marinov and Pastucha add that a relative risk of being obese in 35 years is in the presence of obesity in the age range 1 - 6 years two times higher, 5 - 10 years five times higher, 10 - 14 years ten times higher and 15 - 18 years fifty times higher than in healthy individuals [3].

One of the main reasons for obesity and overweight in children are genetic factors, the behaviour itself, but also the family environment in which the child grows up [4].

Accordingly, body composition assessment achieves a vital position in studies on nutrition, physical activity and health due to an important role of the organ components in human health, particularly when it comes to the impact of excess body fat and the primary factors of chronic diseases [5].

The authors consider that in evaluating the body mass index (BMI), this parameter is one of the assessment criteria of a national standard which was created on the basis of monitoring anthropometric parameters of individuals in a particular country [6]. Further, body mass index acquires the minimum values around the age of 6 years in the individual's life, rising slowly until adulthood [7].

Most studies assess the level of obesity based on anthropometric measurements such as BMI and standard deviation of weight and height scores. Although the body mass index does not estimate the quantity of fat in the body, it remains the most used method for assessing the degree of obesity due to its availability.

The body mass index is an essential indicator of nutrition and indicator of health risk [8].

Several methods are available to assess the body composition, and the criteria that should be taken into account when choosing a proper method of determining it. These include the space the individual intends to assess, costs, the validity/reliability of obtained values, the applicability of the method, and the level of training necessary for an examiner [9].

Between 5 and 11 years, there are some continually increasing parameters of body composition which are observable in both genders, i.e. fat-free mass (FFM), fat mass (FM) and percentage of body fat (PBF) [10].

Fat mass (FM), not body weight (BW), is the best parameter for assessing health and condition. Assessing body composition should be an inseparable part of the health and fitness profile of condition of each individual regardless of body weight [11].

\section{Material and methods}

The research involved children in pre-school and younger school age. The monitored sample consisted of 78 probands at the age of $4-11$ years. The study was performed using the form of a cross-sectional study where the monitored group was divided into four age groups: group I, 4 - 5 year-olds (13 probands) $5.17 \pm 0.52$ years; group II, 6 - 7 year-olds (30 probands) $6.99 \pm 0.52$ years; group III, 8 - 9 year-olds (25 probands) $8.8 \pm 0.52$ years, and group IV, 10 - 11 year-olds (10 probands) $10.92 \pm 0.53$ years.

We tested the essential somatic indicators: body height, body weight and BMI. Body height was measured using an anthropometer. Besides, we applied the diagnostic device InBody 120 (Biospace Co., Ltd.; Seoul, Korea) to assess body weight.

We used the InBody 120 device (Biospace Co., Ltd., Seoul, Korea) to diagnose parameters of body composition. The results of body composition parameters were obtained using a direct analysis of segment multi-frequency bioelectric impedance. The InBody device had been chosen mainly for its ability to analyse a wide range of values of human body composition, but also for its clinical reliability $(r=0.974)$. Using the method of 8-point tactile electrodes, the device diagnoses the body by segment using the most accurate technology DSM-BIA. InBody technology DSM-BIA directly divides a human body into 5 segments $(2$ upper extremities, 2 lower extremities and torso); due to a different composition and different resistance, it is possible to determine as accurately as possible the ratio of individual substances in the body. We recorded the history of measurements using the database software Lookin'Body120 version 1.2.2.7. Bioelectrical impedance (BIA) is a relatively simple, fast and non-invasive method for evaluating the body composition. Besides, it is widely used due to its reliability. This method detects parameters of body composition utilising a small alternating current [12]. Out of the measured 
values of impedance and other corrections presented by [13], we analysed the percentage of body fat (PBF), skeletal muscle mass (SMM), visceral fat level (VFL), waist to hip ratio (WHR), total body water (TBW), protein mass (PM), mineral mass (MM) and basal metabolic rate (BMR).

All the tested individuals turned out to be healthy and did not exhibit any signs of disturbances in the body development. At first, the probands were informed about the tests' performance and evaluation methodology. Before the survey, we received informed consent from the parents about the possibility of implementing the study. The research has been approved by the ethics committee Matej Bel University in Banská Bystrica.

Primary statistical characteristics were used in the survey, i.e. the arithmetic mean, standard deviation, maximum and minimum. The statistical significance concerning physical development and performance between genders was determined using a t-test. An ANOVA was used to evaluate the statistically significant variations in the level of physical performance among the age groups. Statistical dependence was assessed at significance level $\mathrm{p}<0.05$.

\section{Results}

The findings into the level of body development and body composition parameters point to the linear dependencies of differences between age groups (Table 1).

Table 1. Physical development parameters and body composition between age groups

\begin{tabular}{|c|c|c|c|c|c|}
\hline & $\begin{array}{c}\mathbf{4}-\mathbf{5} \text { years } \\
(\mathbf{n = 1 3})\end{array}$ & $\begin{array}{c}\mathbf{6}-\mathbf{7} \text { years } \\
(\mathbf{n = 3 0})\end{array}$ & $\begin{array}{c}\mathbf{8}-\mathbf{9} \text { years } \\
(\mathbf{n = 2 5})\end{array}$ & $\begin{array}{c}\mathbf{1 0}-\mathbf{1 1} \text { years } \\
\mathbf{( n = 1 0 )}\end{array}$ & $\begin{array}{c}\text { ANOVA } \\
\text { (p-value) }\end{array}$ \\
\hline BH [cm] & $113.46 \pm 3.57$ & $125.03 \pm 6.1$ & $135.32 \pm 4.4$ & $144.5 \pm 5.76$ & $3.76 \mathrm{E}-24^{*}$ \\
\hline BW [kg] & $19.48 \pm 2.66$ & $25.03 \pm 3.21$ & $30.61 \pm 4.43$ & $33.58 \pm 3.02$ & $4.65 \mathrm{E}-16^{*}$ \\
\hline BMI [kg.m $\left.{ }^{-2}\right]$ & $15.08 \pm 1.39$ & $16.02 \pm 1.87$ & $16.08 \pm 0.99$ & $16.64 \pm 2.07$ & 0.0975 \\
\hline PBF [\%] & $14.79 \pm 3.2$ & $16.2 \pm 6.64$ & $15.69 \pm 6.38$ & $13.74 \pm 4.5$ & 0.6756 \\
\hline FM [kg] & $2.93 \pm 0.96$ & $4.15 \pm 2.21$ & $4.89 \pm 1.39$ & $5.01 \pm 2.81$ & $0.0475^{*}$ \\
\hline SMM [kg] & $7.7 \pm 1.17$ & $10.31 \pm 1.44$ & $13.15 \pm 1.51$ & $15.22 \pm 1.99$ & $1.31 \mathrm{E}-20^{*}$ \\
\hline VFL [i] & $1.38 \pm 0.51$ & $1.43 \pm 0.94$ & $1.6 \pm 1.04$ & $1.2 \pm 0.42$ & 0.6492 \\
\hline WHR [i] & $0.71 \pm 0.03$ & $0.72 \pm 0.03$ & $0.74 \pm 0.05$ & $0.72 \pm 0.02$ & 0.1197 \\
\hline TBW [L] & $12.11 \pm 1.43$ & $15.28 \pm 1.77$ & $18.74 \pm 1.86$ & $21.26 \pm 2.43$ & $2.23 \mathrm{E}-20^{*}$ \\
\hline PM [kg] & $3.22 \pm 0.38$ & $4.09 \pm 0.48$ & $5.01 \pm 0.5$ & $5.71 \pm 0.66$ & $1.83 \mathrm{E}-20^{*}$ \\
\hline MM [kg] & $1.23 \pm 0.11$ & $1.48 \pm 0.17$ & $1.78 \pm 0.17$ & $2.03 \pm 0.21$ & $2.06 \mathrm{E}-19 *$ \\
\hline BMR [kcal] & $726.92 \pm 41.2$ & $819.8 \pm 51.8$ & $921.12 \pm 54.4$ & $995.8 \pm 71.39$ & $1.77 \mathrm{E}-20^{*}$ \\
\hline
\end{tabular}

Note: BH - body height, BW - body weight, BMI - body mass index, PBF - percentage of body fat, FM - fat mass, SMM - skeletal muscle mass, VFL - visceral fat level, WHR - waist to hip ratio, TBW - total body water, PM - protein mass, MM - mineral mass, BMR - basal metabolic rate, ${ }^{*}$ - statistical significant $\mathrm{p}<0.05$

There were noted statistically significant changes between age groups in particular parameters of body development. In body height, there was shown a statistical significant $(p<0.05)$ change between age groups of selected subjects $\mathrm{p}=3.76 \mathrm{E}-24$. Our results strongly correspond to the theoretical assumptions on the linear development of body height in children and adolescents (Figure 1).

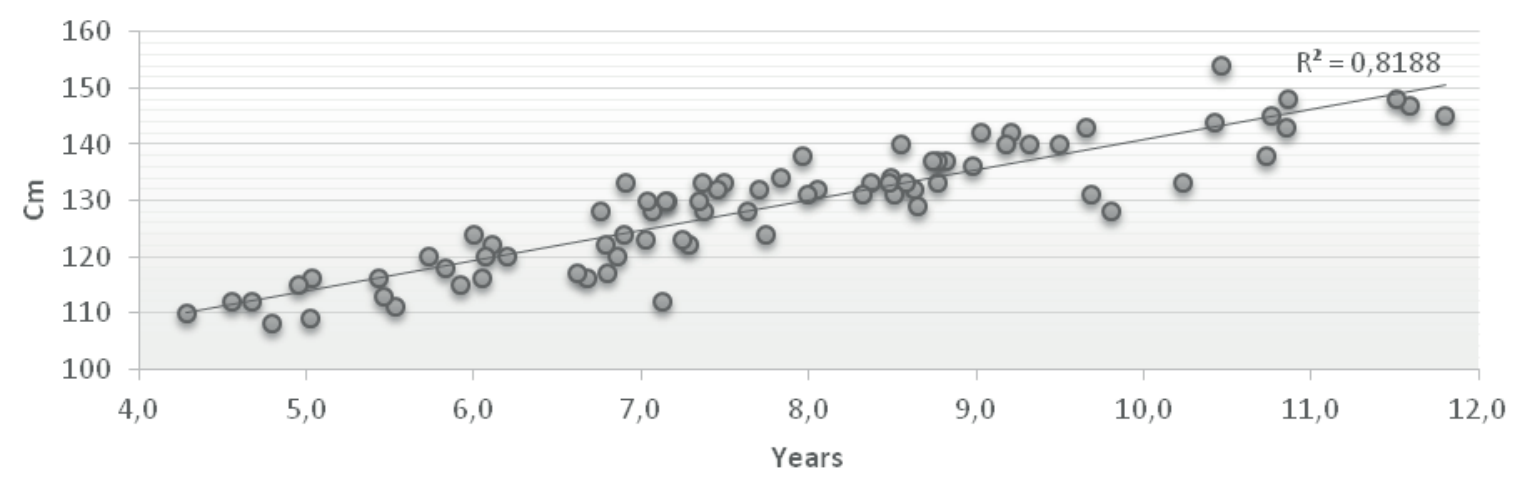

Figure 1. Body height and age dependency 
In body weight, a statistically significant variation $(\mathrm{p}<0.05)$ was shown between the age groups of the selected subjects $\mathrm{p}=4.65 \mathrm{E}-16$. The highest increase in body height and body weight was observed between the 4-5-year-olds and 6-7-year-olds. On the contrary, the smallest increase was evidenced between the 8-9-yearolds and 10-11-year-olds.

Our results correspond to the theoretical assumptions on the linear development of body weight in children and adolescents (Figure 2).

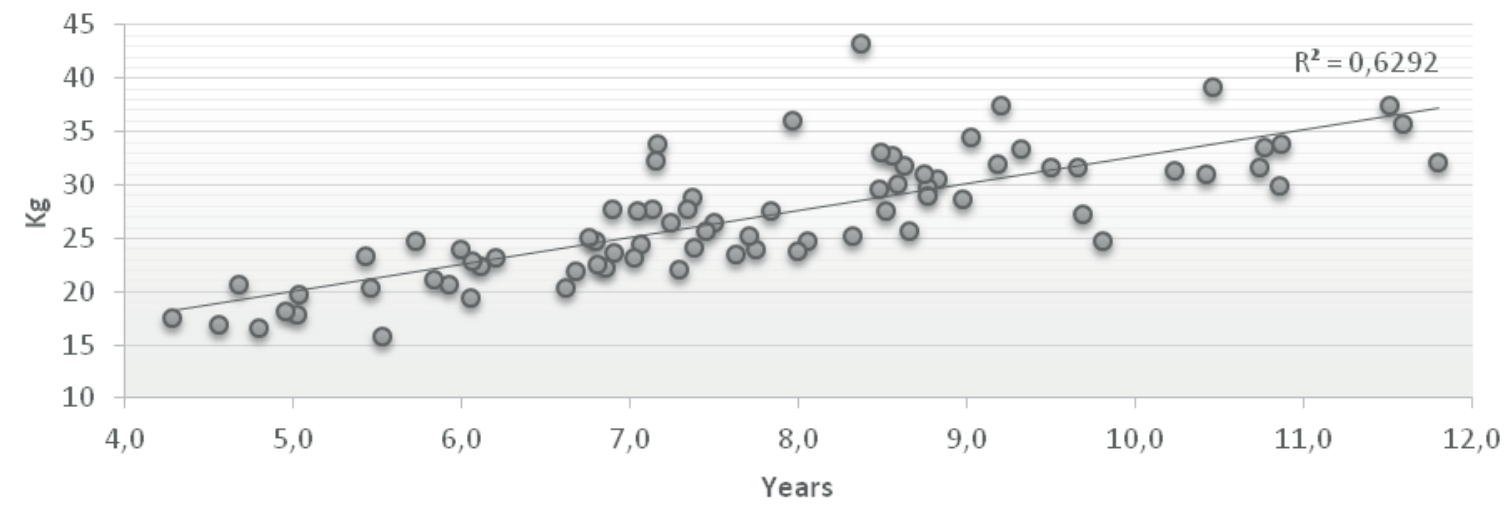

Figure 2. Body weight and age dependency

In body mass index, a slight linear growth was recorded in BMI with increasing age. A statistically significant difference $(p>0.05)$ between the age groups of the selected subjects $p=0.0975$ was not shown (Figure 3 ).

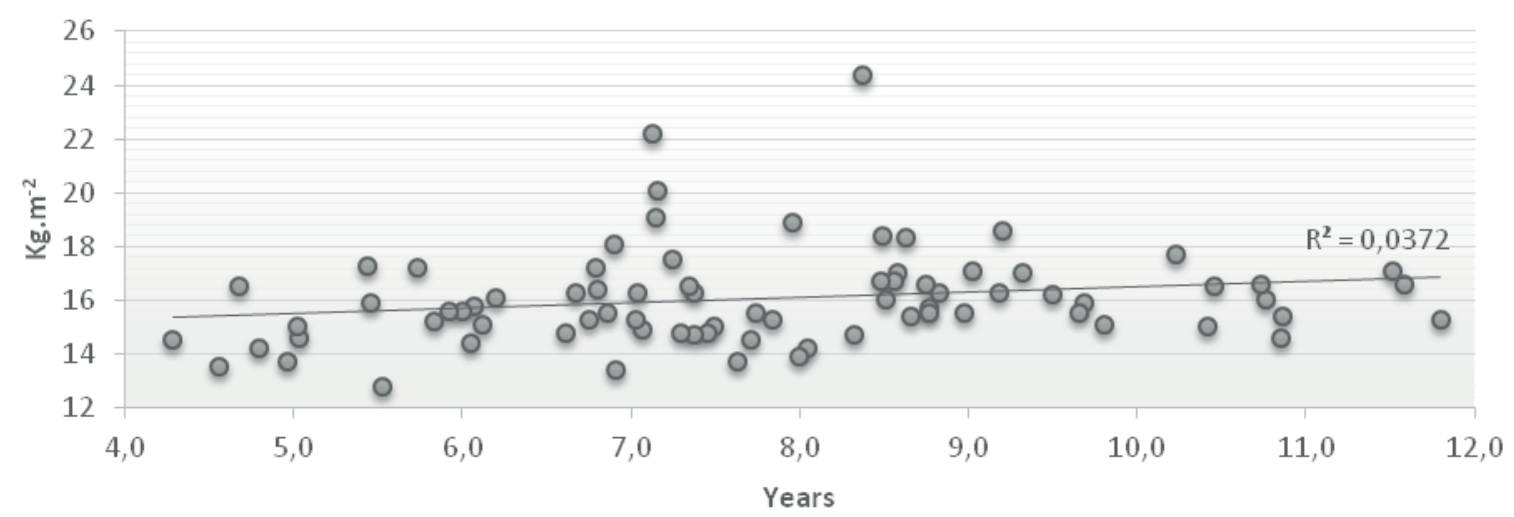

Figure 3. BMI and age dependency

In the parameter percentage of body fat (PBF), there was not shown a statistically significant difference between the age groups. The changes were fluctuating with the reduction in fat rate from the age of $6-7$. Since this parameter indicates the rate of fat mass (FM) and total weight (TW), significant changes take place in the parameters of fat mass in a body increasing the total body weight.

In fat mass (FM), a slight linear growth was recorded with increasing age. A statistically significant variation $(p<0.05)$ was shown between the age groups of the selected subjects $p=0.475$ (Figure 4 ). 


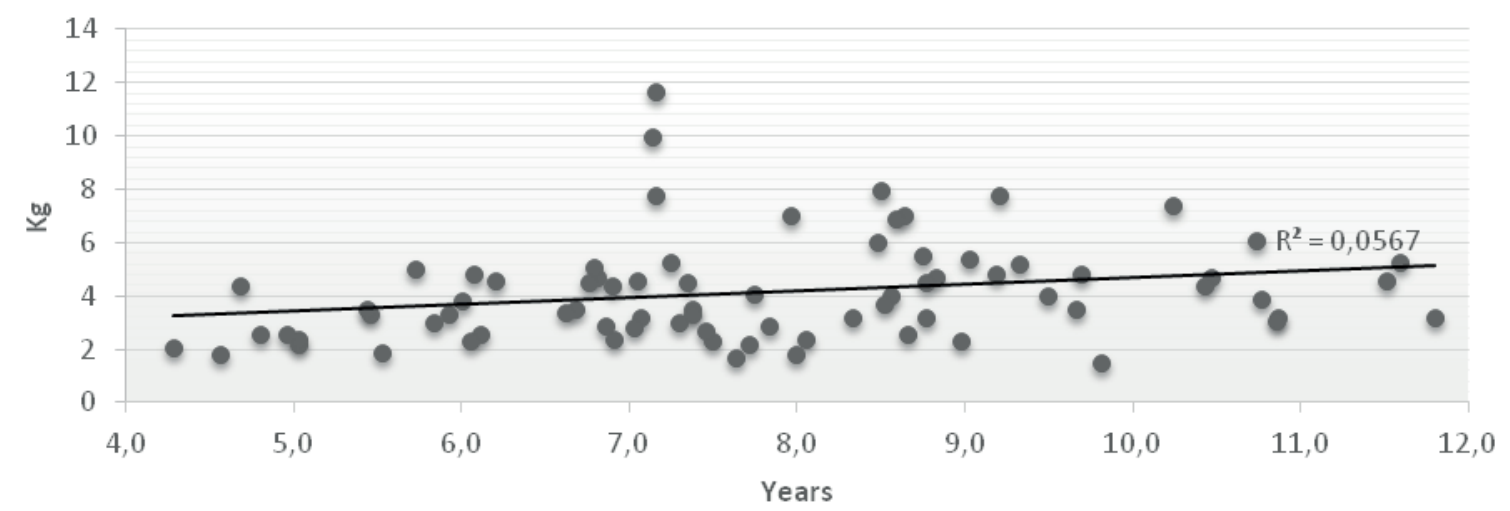

Figure 4. Fat mass (FM) and age dependency

In skeletal muscle mass, a linear growth was recorded with increasing age. A statistically significant change $(\mathrm{p}<0.05)$ between the age groups of the selected subjects was shown $\mathrm{p}=1.31 \mathrm{E}-20$ (Figure 5).

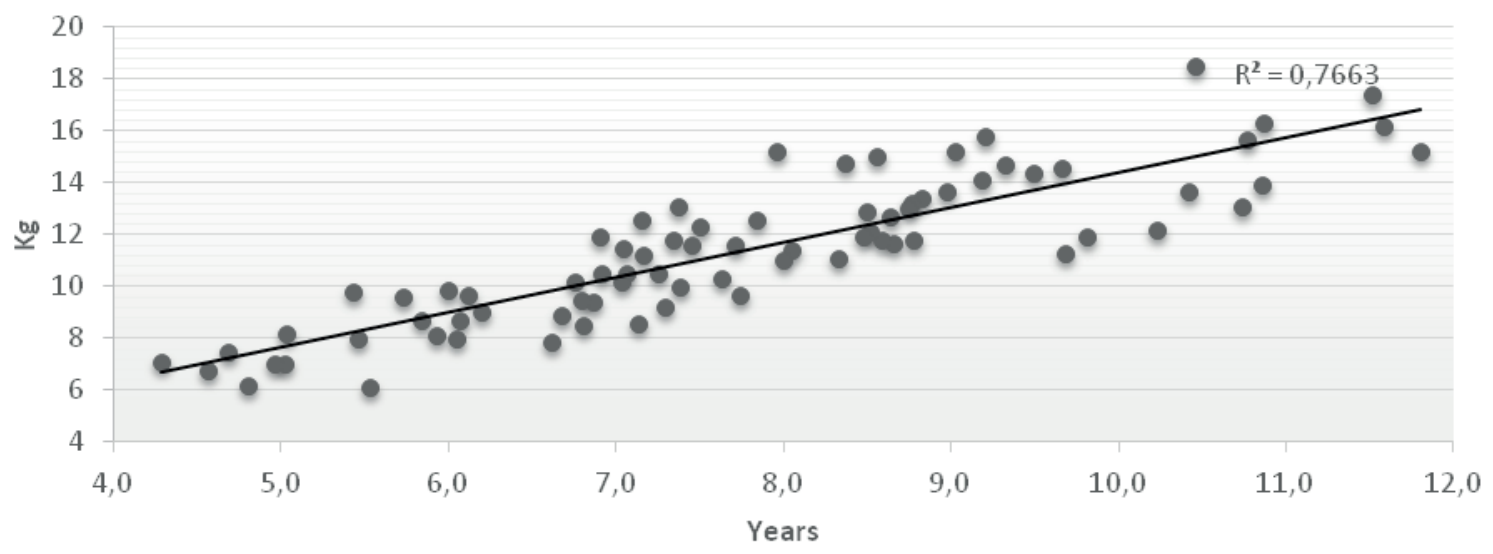

Figure 5. Skeletal muscle mass (SMM) and age dependency

There is no linear dependence on age in these parameters: visceral fat level (VFL) and waist to hip ratio (WHR), as it sticks to the index rating. Only small, but not statistically significant differences were recorded in the above-mentioned parameters.

In total body water (TBW), a linear growth was recorded with increasing age. A statistically significant ( $\mathrm{p}<$ 0.05 ) difference between the age groups of selected subjects was shown $\mathrm{p}=2.23 \mathrm{E}-20$ (Figure 6).

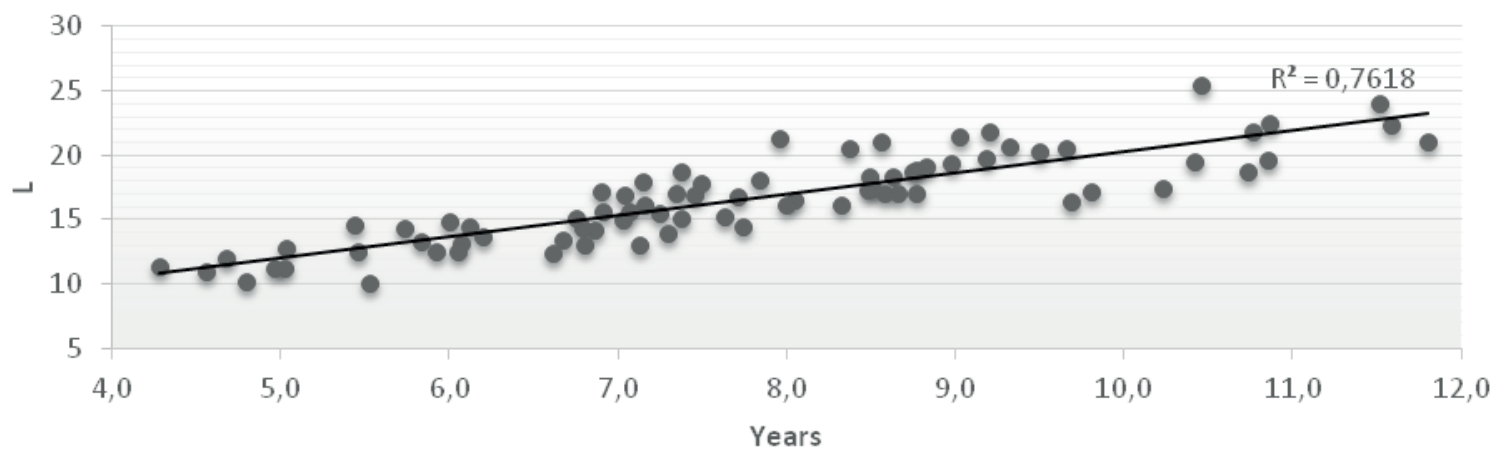

Figure 6. Total body water (TBW) and age dependency

In protein mass (PM), a linear growth was recorded with increasing age. A statistically significant change (p $<0.05$ ) was shown between the age groups of the selected subjects $\mathrm{p}=1.83 \mathrm{E}-20$ (Figure 7). 


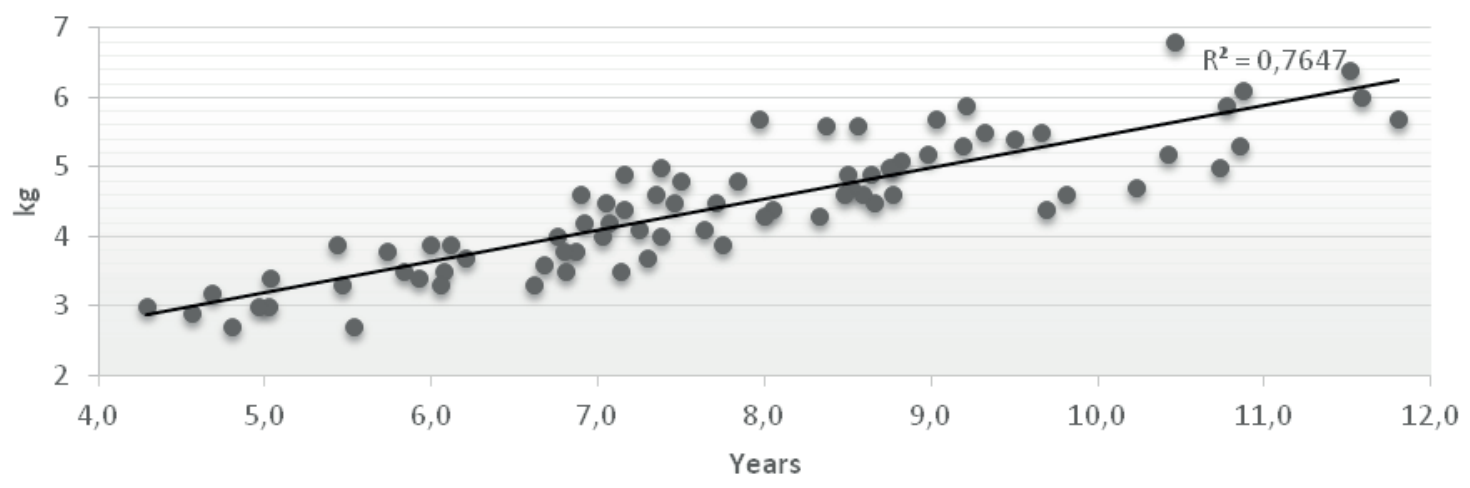

Figure 7. Protein mass (PM) and age dependency

In mineral mass (MM), a linear growth was recorded with increasing age. A statistically significant variation $(p<0.05)$ was shown between the age groups of the selected subjects $p=2.06 \mathrm{E}-19$ (Figure 8).

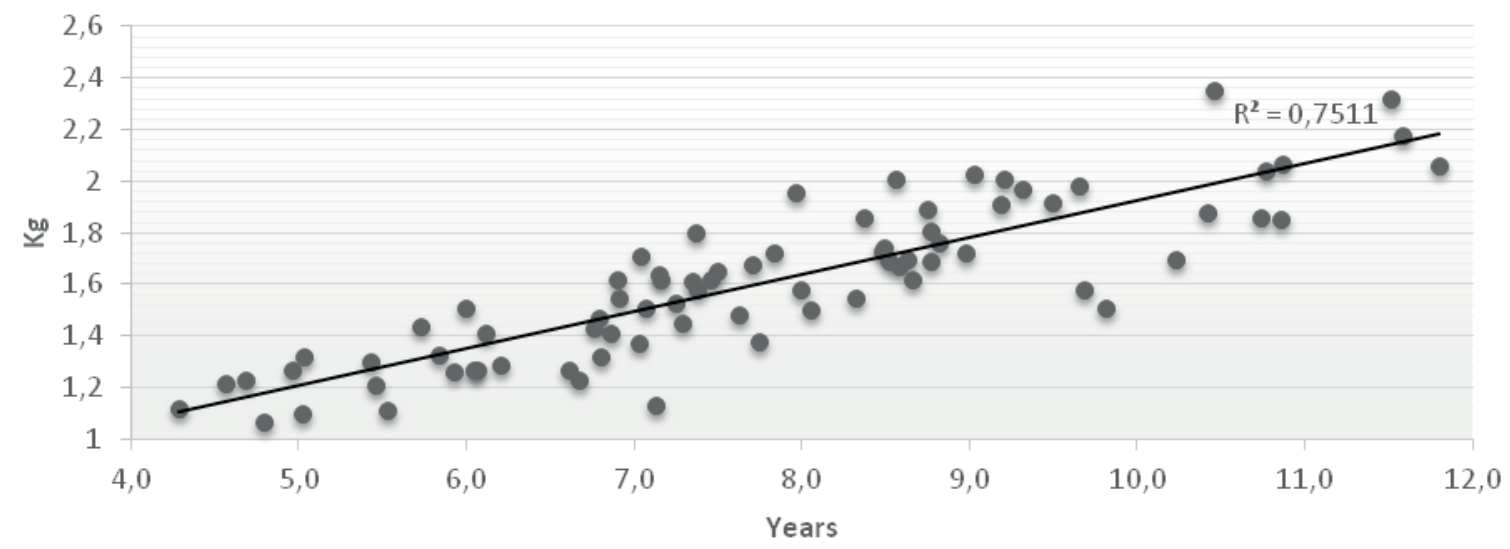

Figure 8. Mineral mass (MM) and age dependency

In the level of basal metabolic rate (BMR), a linear growth was recorded with increasing age. A statistically significant change $(\mathrm{p}<0.05)$ was shown between the age groups of the selected subjects $\mathrm{p}=1.77 \mathrm{E}-20$ (Figure 9).

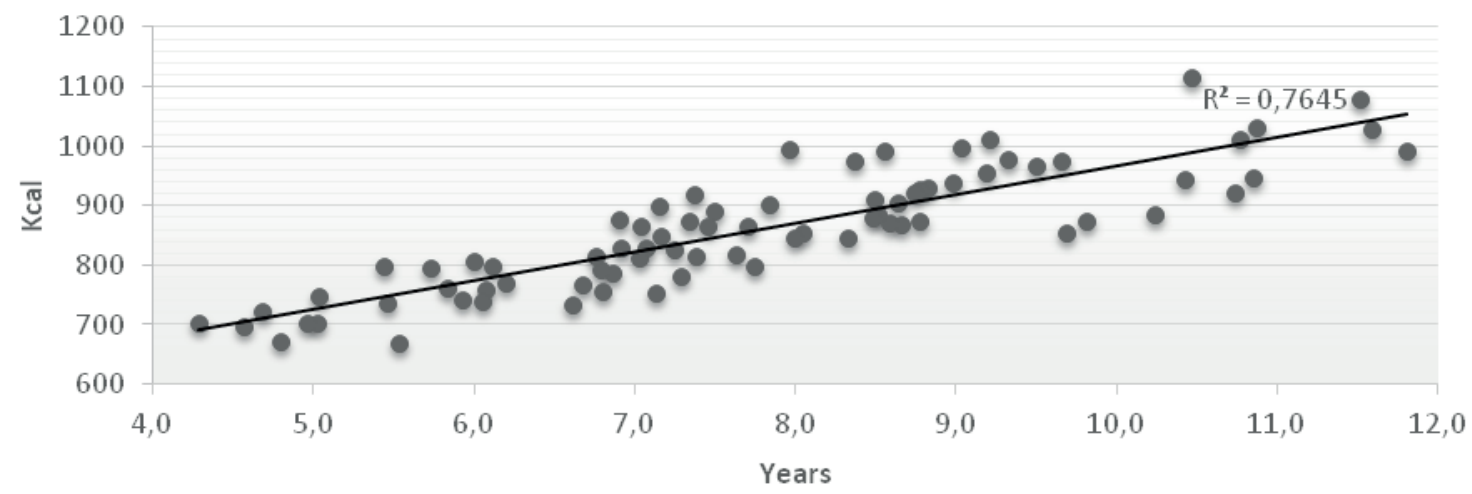

Figure 9. Basal metabolic rate (BMR) and age dependency

\section{Discussion}

Based on the results of the VII National survey, the fact was revealed about how the acceleration trends in the mentioned population groups in growth and the secular trend gradually stops. However, an accelerated increase of body weight values is negative when the growth slows down, which was reflected in a significant increase 
of average BMI values in all age groups of boys and girls as well as in higher peripheral rates [14]. Our results of body height and body weight correspond to the general developmental trends. The BMI values correspond to the developmental trend but they differ in values of comparable age groups in those probands have reached lower values than the Slovak population [14].

The authors focused on comparing the quantity of body activity in 5-7-year-old children from the Prešov region and their body composition parameters. In the tested sample, an average body height $-116.1 \mathrm{~cm}$, body weight $23.5 \mathrm{~kg}$, BMI $15.75 \mathrm{~kg} \cdot \mathrm{m}^{-2}$ were recorded. In body composition parameters, there were recorded on average $8.2 \mathrm{~kg}$ of skeletal muscle mass, $18.2 \%$ of fat mass, $3.37 \mathrm{~kg}$ of proteins, and $1.19 \mathrm{~kg}$ of minerals. The waist to hip ratio was $0.74-0.75$ and the level of basal metabolism was $728.1 \mathrm{kcal}$ in girls and $758.6 \mathrm{kcal}$ in boys. Our results of 6-7-year-old children are higher in the parameters of physical development. Our probands achieved lower values in the parameters indicating the risk of obesity, fat mass (FM) and waist to hip ratio (WHR). As for the intersexual comparison, there were not noticed any significant changes in the parameters of body composition, except for the parameters concerning the nutritional status (quantity of minerals and proteins) [15].

Comparing our results with the research implemented on children in South Africa [16], we notice differences with our group. In body mass index, there are found lower values compared to our research. They recorded 13.6 kg.mm ${ }^{-2}$ in 7 year-old children, $13.9 \mathrm{~kg} . \mathrm{m}^{-2}$ in 8 year-olds, $14.15 \mathrm{~kg} \mathrm{~m}^{-2}$ in 9 year-olds. In percentage of body fat parameter (PBF), there was evidenced $12.8-16.8 \%$ in 7 year-old children, $13.1-17.8 \%$ in 8 year-olds and 12.9 $16.1 \%$ in 9 year-olds. Thus, the authors may conclude that $77 \%$ of the population was malnourished and no child was classified as overweight. These results are caused by regional differences.

When comparing our findings with the research results in the study implemented on the UK pupil populations $[17,18]$, we note partial differences between the age groups. In 5-7-year-old children, the average body height is $120.9 \mathrm{~cm}$, body weight $22.7 \mathrm{~kg}$ and BMI $15.4 \mathrm{~kg} . \mathrm{m}^{-2}$. They recorded $6.2 \mathrm{~kg}$ of skeletal muscle mass (SMM) in the group, but our group achieved significantly higher values. In 8-10-year-old children, the average body height is $137.3 \mathrm{~cm}$, body weight is $33.9 \mathrm{~kg}$ and BMI is $17.75 \mathrm{~kg} . \mathrm{m}^{-2}$. They point to $9.55 \mathrm{~kg}$ of skeletal muscle mass (SMM) in the group, but our probands reached significantly higher values. In our groups, we recorded significantly higher values of skeletal muscle mass for total body weight and lower values of fat mass.

In turn, a cross-sectional study which examined 332 boys and 269 girls at the age of 8 to 11 in Turkey showed that girls had demonstrated a higher body fat mass. In the presented study, they noted expected results according to the age groups in the anthropometric parameters and parameters of body composition. Higher values of fatfree body mass (FFM) were recorded in boys when compared to girls. A higher value of WHR was observed in boys when compared to girls. However, girls had higher values of fat mass (FM) and percentage of body fat (PBF) when compared to boys. In the monitored groups, there were recorded significantly higher values of percentage of body fat than found in the present survey. The average percentage of fat at the age of 8 is $16.3 \%$. The highest fat mass values $17.2 \%$ were noted at the age of 11 . Fat mass (FM) increases in both genders in all monitored age groups [19].

\section{Conclusions}

In most indicators of body development and body composition, there were recorded statistically significant differences $(\mathrm{p}<0.05)$ and linear dependence between the age groups. In body mass index (BMI), we recorded slightly increasing values. We did not notice significant differences between groups in the following indicators: percentage of body fat (PBF), visceral fat level (VFL), and waist to hip ratio (WHR). The positive thing is that risk factors of obesity do not significantly increase with an increasing age with regard to BMI and the waist to hip ratio.

The necessary somatic parameters of the physical development of the monitored children correspond to the secular trend and the linear growth of the National Anthropometric Measurements [14]. BMI values respond to the developmental trend, but they differ in the achieved values of comparable age groups as our probands have achieved lower values than the whole population of children from Slovakia.

When comparing our findings with the previous research, we recorded lower values of risk factors of obesity in our groups than in children of the Slovak population [14]. When comparing them with international research findings, our results differ in the achieved values, which may be caused by regional differences.

\section{Acknowledgements}

This paper is a part of the research project VEGA 1/0571/16 The impact of training on physical abilities, physical and functional development of 5-6-year-old children. 


\section{References:}

1. World Health Organization. Childhood overweight and Obesity. [cited 2017 Jul 03]. Available from: http:// www.who.int/dietphysicalactivity/childhood/en/.

2. Singh AS, Mulder C, Twisk JW, van Mechelen W, Chinapaw MJ. Tracking of childhood overweight into adulthood: a systematic review of the literature. Obesity Reviews. 2008; 9(5): 474-488. https://www.doi.org/10.1111/j.1467-789X.2008.00475.x

3. Marinov Z, Pastucha D. Praktická dětská obezitologie. Praha: Grada; 2012 (in Czech).

4. Ahmad QI, Ahmad CB, Ahmad SM. Childhood obesity. Indian J Endocrinol Metab. 2010; 14(1): 19-25.

5. Rezende F, Rosado L, Franceschinni S, Rosado G, Ribeiro R, Marins JCB. Revisão crítica dos métodos disponíveis para avaliar a composição corporal em grandes estudos populacionais e clínicos. Archivos Latinoamericyears de Nutricion. 2007; 57(4): 327-334 (in Spanish).

6. Medeková, H, Šelingerová M. Diferenciácia vývinu niektorých somatických znakov detí z hl’adiska ich pohybovej aktivity. In: Physical education and sports - teachers' preparation and their employability in Europe. Bratislava: FTVŠ UK; 2007. p. 622-627 (in Slovak).

7. Simmonds M, Burch J, Llewellyn A, Griffiths C, Yang H, Owen Ch, et al. The use of measures of obesity in childhood for predicting obesity and the development of obesity-related diseases in adulthood: a systematic review and meta-analysis. Health Technology Assessment. 2015; 19(43): 1-372. https://doi.org/10.3310/hta19430

8. Janssen I, Katzmarzyk PT, Ross R. Waist circumference and not body mass index explains obesity-related health risk. Am J Clin Nutr. 2004; 79(3): 379-384. https://doi.org/10.1093/ajcn/79.3.379.

9. Mialich MS, Martinez EZ, Jordao Jr. AA. Comparative study of instruments for the analysis of body composition in a sample of the Brazilian population. International Journal of Body Composition. 2011; 9(1): 19-24.

10. Xiong KY, He H, Zhang YM, Ni GX. Analyses of body composition charts among younger and older Chinese children and adolescents aged 5 to 18 years. BMC Public Health. 2012; 12: 835. https://doi.org/10.1186/1471-2458-12-835

11. Dave P, Subhedar R, Mishra P, Sharma D. Body composition parameter changes among young male and female competitive swimmers and nonswimmers. International Journal of Medical Science and Public Health. 2016; 5(1): 85-92. https://doi.org/10.5455/ijmsph.2016.2905201520.

12. Kim CG, Park SH, Kim KH, Kwon YW, Huh Y, Ma MR, et al. Development of new regression equation for estimating body composition by underwater weight. Journal of Korea Sport Research. 2004; 17: 329-340.

13. Kyle UG, Bosaeus I, De Lorenzo AD, Deurenberg P, Elia M, Gómez JM, et al. Bioelectrical impedance analysis part I. Review of principles and methods. Clinical Nutrition. 2004; 23(5): 1226-43. https://doi.org/10.1016/j.clnu.2004.06.004

14. PHASR. Telesný vývoj detí a mládeže v SR : Výsledky VII. celoštátneho prieskumu v roku 2011. [cited 2017 Aug 16]. Available from: http://www.uvzsr.sk/docs/info/hdm/Antropometria.pdf (in Slovak).

15. Junger J, Palanská A, Čech P. Physical activity and body composition of 5 to 7 years old children. Health Problems of Civilization. 2014; 8(3): 12-19. https://doi.org/10.5114/hpc.2014.57080.

16. Monyeki MA, Koppes LLJ, Kemper HCG, Monyeki KD, Toriola AL, Pienaar AE, et al. Body composition and physical fitness of undernourished South African rural primary school children. European Journal of Clinical Nutrition. 2005; 59(7): 877-883. https://doi.org/10.1038/sj.ejcn.1602153.

17. McCarthy HD, Cole TJ, Fry T, Jebb SA, Prentice AM. (2006). Body fat reference curves for children. Int J Obes. 2006; 30(4): 598-602. https://doi.org/10.1038/sj.ijo.0803232.

18. McCarthy HD, Samani-Radia D, Jebb SA, Prentice AM. Skeletal muscle mass reference curves for children and adolescents. Pediatric Obesity. 2014; 9(4): 249-259. https://doi.org/10.1111/j.2047-6310.2013.00168.x.

19. Gültekin T, Akin G, Ozer BK. Gender differences in fat patterning in children living in Ankara. Anthropol Anz. 2005; 63(4): 427-437. 